\title{
SISTEM INFORMASI PENGELOLAAN ANGGARAN DENGAN METODE R\&D
}

\author{
Myra Andriana ${ }^{1}$, Roymon Panjaitan', Tantik Sumarlin ${ }^{3}$ \\ ${ }^{1}$ Komputer Akuntansi, Universitas Sains dan Teknologi Komputer, Semarang \\ Indonesia \\ ${ }^{2}$ Komputer dan Bisnis, Universitas Sains dan Teknologi Komputer, Semarang \\ Indonesia \\ ${ }^{3}$ Komputer Akuntansi, Universitas Sains dan Teknologi Komputer, Semarang \\ Indonesia
}

Email: ${ }^{1}$ myra.andriana@stekom.ac.id, ${ }^{2}$ roymon@stekom.ac,id, ${ }^{3}$ tantiksumarlin@yahoo.co.id

*Corresponding Author: myra.andriana@stekom.ac.id

\begin{abstract}
Budget is an important thing in an organization. Budgeting can assist organizations in conducting control and evaluation to achieve goals. The ineffectiveness of a budget will have an impact on the failure of the previously planned activity program. The purpose of this study is to provide a design of a budget management system that can help users to manage their budgets more efficiently and effectively. This study uses research and development methods. The system is built using Visual Basic.Net, with a MySQL database. The result of this research is the creation of an information system that can help in terms of budget management at SubDirektorat 2 Ditreskrimum Polda Jawa Tengah. This system makes it easy to input budget data and helps to know the budget amount accurately, because it can reduce the potential for errors. In addition, the presentation of reports can be done quickly so that it can be more efficient.
\end{abstract}

Keywords : Information System, Budget, $R \&$ D Method

Abstrak - Anggaran merupakan tahap penting dalam suatu organisasi. Penyusunan anggaran
membantu organisasi dalam melakukan kontrol dan evaluasi dalam mencapai tujuan. Tidak
efektifnya suatu anggaran akan berdampak pada gagalnya program kegiatan yang telah
direncanakan sebelumnya. Tujuan dari studi ini adalah memberikan suatu rancangan sistem
pengelolaan anggaran yang dapat membantu pengguna untuk mengelola anggarannya lebih
efisien dan efektif. Penelitian ini menggunakan metode riset dan pengembangan. Sistem
dibangun dengan menggunakan Visual Basic.Net, dengan database MySQL. Hasil dari penelitian
ini adalah terciptanya suatu sistem informasi yang dapat membantu dalam hal manajemen
anggaran pada Subdit 2 Ditreskrimum Polda Jateng. Sistem ini memudahkan penginputan data
anggaran dan membantu mengetahui jumlah anggaran secara akurat, karena mampu mengurangi
potensi kesalahan. Selain itu penyajian laporan-laporan dapat dilakukan dengan cepat sehingga
dapat lebih efisien.

Keyword: Sistem Informasi, Anggaran, Metode R \& D 


\section{Introduction}

Anggaran merupakan bentuk rencana secara sistematis pada suatu organisasi yang dinyatakan dalam satuan moneter untuk periode waktu tertentu. Penyusunan anggaran akan membantu proses pengendalian dan evaluasi organisasi dalam mencapai tujuannya. Tahap ini sangat penting bagi suatu organisasi karena, tidak efektifnya suatu anggaran akan menyebabkan gagalnya program kegiatan yang telah disusun sebelumya. Permasalahan terkait pengelolaan anggaran umum terjadi. Hal ini dapat diantisipasi dengan manajemen anggaran yang baik, terencana, terukur, serta adanya kontrol terhadap realisasi anggaran. Pemanfaatan teknologi informasi mampu membantu mengatasi permasalahan yang terjadi dalam pengelolaan anggaran (Zarnelly, 2017; Astarina, 2019).

Sistem informasi telah dimanfaatkan dalam penyusunan anggaran di beberapa organisasi. Pemanfaatan sistem informasi berpengaruh positif terdadap efektivitas pengelolaan anggaran (Sukarta et al., 2017). Sistem informasi anggaran mempermudah pengguna dalam menyajikan informasi yang cepat dan akurat dalam penyusunan dan penggunaan anggaran (Eka dan Aeri, 2016). Selain itu, dengan digunakannya sistem informasi anggaran akan mempermudah pengguna dalam menyesuaikan antara ketersediaan dana dengan anggaran belanja. Sehingga, pemanfaatan dana pada sebuah organisasi dapat efektif dan efisien sesuai dengan program kegiatan yang telah direncanakan. Namun faktanya, masih ada lembaga yang melakukan proses penganggaran secara manual. Tingginya potensi kesalahan menyebabkan tidak akuratnya informasi yang dihasilkan dalam penggunaan sistem manual.

Permasalahan terkait dengan pengelolaan anggaran juga terjadi pada Sub Direktorat (Subdit) 2 Ditkreskrimum Polda Jateng, yang merupakan bagian dari Institusi Kepolisian Republik Indonesia wilayah Jawa Tengah yang menangani kasus-kasus kejahatan konvensional seperti penipuan, penggelapan, pemalsuan surat dan penyerobotan tanah. Dalam menangani berbagai kasus, Subdit 2 Ditreskrimum Polda Jateng membutuhkan anggaran yang digunakan dalam melakukan kegiatan penyelidikan dan penyidikan. Hasil observasi menunjukkan dalam pengelolaan anggaran, Subdit 2 Ditreskrimum Polda Jateng masih menggunakan aplikasi Microsoft Word. Hal tersebut menyebabkan tidak maksimalnya pengelolaan anggaran. Human error seperti salah hitung dan salah pencatatan serta pencarian arisp yang membutuhkan waktu lama, menyebabkan laporan penggunaan anggaran yang disusun tidak akurat dan efisien. 
Dari berbagai permasalahan terkait dengan pengelolaan anggaran pada Subdit 2 Ditkreskrimum, maka pada penelitian ini akan dirancang sebuah sistem informasi pengelolaan anggaran dengan metode budgetary accounting. Dengan dibangunnya sebuah sistem pengelolaan anggaran pada Subdit 2 Ditkreskrimum, diharapkan mempermudah pengguna dalam menyesuaikan dana yang ada dengan anggaran belanja. Selain itu, diharapkan mampu membantu mereduksi permasalahan terkait dengan pengelolaan anggaran serta mempermudah pengguna untuk menyajikan informasi anggaran yang lebih akurat dan tepat waktu. Sistem informasi akan meningkatkan efektivitas dan efisiensi pengelolaan anggaran (Fitri et al., 2019; Ai Rosita, 2018)

\section{Materials and Methods}

\subsection{Sistem}

Sistem adalah kumpulan dari beberapa sumber daya yang memiliki keterkaitan dan saling bekerja sama untuk mencapai suatu tujuan dan sasaran dalam ruang lingkup yang sempit (Kusnendi, 2014). Pemahaman ini juga diperkuat dengan adanya sistem menghubungkan perencanaan, pengelolaan, tujuan, fungsi dan komunikasi pemasaran konvensional, online sampai dengan pemasaran terpadu bagi pelaku bisnis (Sutabri \& Napitupulu, 2019).

\subsection{Sistem Informasi}

Sistem informasi adalah kumpulan elemen, komponen atau subsistem yang saling terintegrasi dan berinteraksi untuk mencapai tujuan tertentu (Mulyanto, 2015).Sistem informasi terdiri dari komponen-komponen yang disebut blok bangunan (building block), yang terdiri dari blok masukan, blok model, blok keluaran, blok teknologi, blok basis data, dan blok kendali. Sebagai suatu sistem, keenam blok tersebut saling berinteraksi membentuk suatu kesatuan untuk mencapai sasaran (Sutrabi, 2012). Peran dasar sistem informasi sebagai salah satu sistem teknologi informasi digunakan untuk pengolahan transaksi TPS (Transaction Processing Sistems) dengan menggantikan pengolahan transaksi oleh manusia dengan teknologi sistem informasi. Dimana kegunaannya berorientasi untuk meningkatkan efisiensi. Peran efisiensi lainnya juga dicapai oleh PCS (Process Control Sistem) yang menggantikan manusia dengan teknologi di proses produksi. Menurut (Wang \& Kogan, 2018) transaksi berbasis blockchain (TPS) menunjukkan fungsionalitas TPS dalam akuntansi real-time, pemantauan berkelanjutan dan pencegahan penipuan untuk mendukung sistem informasi. 


\subsection{Anggaran}

Anggaran adalah rencana kerja yang dituangkan dalam angka-angka keuangan baik jangka pendek maupun jangka panjang yang merupakan suatu rencana kuantitatif periodik yang disusun berdasar program yang telah disahkan (Anita dan Irwinsyah, 2019). Anggaran memiliki beberapa fungsi diantaranya sebagai perencanaan, pengawasan, koordinasi dan pedoman kerja. Anggaran bukan saja memperkirakan biaya, tetapi juga pendapatan perusahaan. Secara umum, anggaran belanja merujuk pada seluruh daftar rencana biaya dan pendapatan.

\subsection{Budgetary Accounting}

Budgetary accounting akan menguraikan aktivitas keuangan dalam jangka waktu tertentu yang dijalankan melalui sistem analisa dan pengawasan. Dalam penerapannya, budgetary accounting merupakan teknik akuntansi yang berperan untuk mencatat setiap peristiwa transaksi yang terjadi, yang terdapat pada setiap anggaran mulai sejak pengesahan anggaran, dialokasikan ataupun dilaksanakan hingga saat penutupan buku akhir periode. Tujuan budgetary accounting adalah untuk mengendalikan anggaran serta memberikan informasi yang bermanfaat bagi pengelolaan dan control anggaran, sehingga dapat diketahui tingkat efisiensi dan efektifitasnya.

\subsection{Sistem Informasi Anggaran}

Sistem informasi anggaran adalah sarana yang dapat digunakan untuk mempermudah proses penganggaran (Rosita, 2018; Windi dan Eka, 2018). Sistem ini mampu memenuhi kebutuhan pengguna dalam menyajikan informasi keuangan, khususnya terkait dengan anggaran yang efektif dan efisien. Volume data yang semakin tinggi membutuhkan pengelolaan yang baik sehingga memudahkan penggunanya dalam memperoleh informasi untuk pengambilan keputusan. Sistem informasi anggaran akan membantu mengelola data keuangan dengan baik, sehingga memudahkan penggunanya untuk memperoleh informasi. Penggunaan aplikasi, mempermudah penginputan dan pengolahan transaksi untuk menghasilkan laporan yang lebih efektif serta untuk meminimalisir kesalahan (Nining dan Kaslani, 2018; Arta et al., 2011)

\subsection{Metode $R \& D$}

Dalam pengembangan produk ini yaitu dengan metode R \& D menurut (Sugiyono, 2016) terdiri dari 6 tahapan dalam model ini yaitu : (1) mengidentifikasikan potensi maslah, (2) penelitian dan pengumpulan data, (3) perancangan, (4) uji validasi 
desain, (5) validasi prouk dan terakhir (6) penerapan produk. Adapun gambar dari alur pengembangan model peneitian produk seperti gambar dibawah ini :

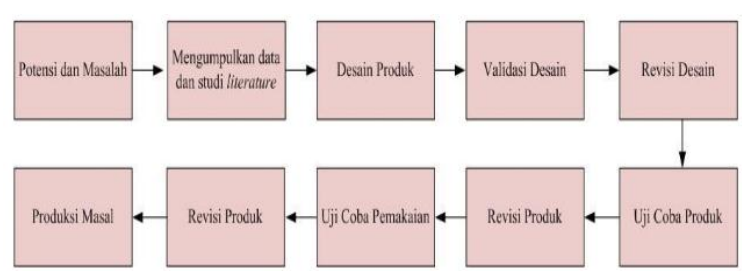

Gambar 1. Pengembangan Model

Sumber : Sugiyono, 2015

Penjelasan singkat tahap pengembangan:

a. Identifikasi Potensi Permasalahan

Langkah awal dari kerangka berpikir adalah mengidentifikasi masalah yang ada di perusahaan. Dalam hal ini penulis menganalisis berbagai permasalahan yang di alami user. Permasalahan yang terjadi antara lain belum adanya sistem informasi anggaran yang terintegrasi dan belum memiliki database sehingga dalam pencarian data serta pembuatan laporan menjadi kurang efektif dan efisien.

\section{b. Penelitian dan Pengumpulan Data}

Teknik pengumpulan data yang dilakukan penulis adalah studi literatur yang diperoleh dari buku dan jurnal dan studi lapangan berupa wawancara pada staff yang mengelola anggaran dan observasi secara langsung. c. Perancangan

Tahap perancangan sistem berisi gambar ataupun bagan yang menerangkan proses kerja sistem informasi. Tahap perancangan menggunakan diagram UML yaitu sebagai berikut: Use Case Diagram, Sequence Diagram, Activity Diagram, Class Diagram.

\section{d. Uji Validasi Desain}

Uji Validasi Program menggunakan angket likert yang diarahkan kepada ahli (validator desain dan sistem) serta pengguna sistem.

\section{e. Validasi Produk}

Jika validasi produk dianggap sesuai maka dapat berlanjut pada tahap penerapan produk. Namun, apabila uji validasi produk dinyatakan gagal maka akan kembali lagi ketahap perancangan produk.

\section{f. Penerapan Produk}

Setelah seluruh tahapan selesai, diamana sistem sudah sesuai dengan ekspektasi maka dapat dilanjutkan ke tahap terakhir yaitu implementasi produk. 


\section{Results and Discussion}

\subsection{Diagram Activity}

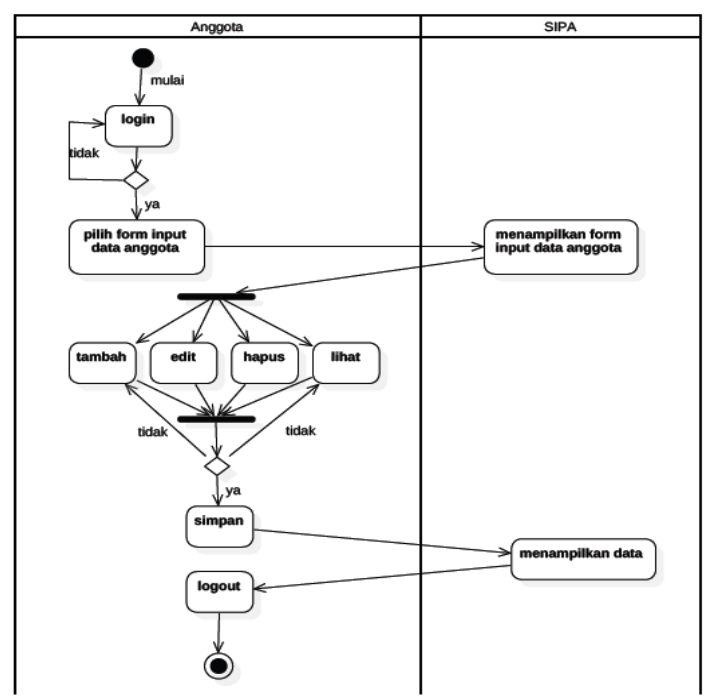

Gambar 2. Activity Diagram Anggota_Kelola

Anggota

Sumber: Data Primer

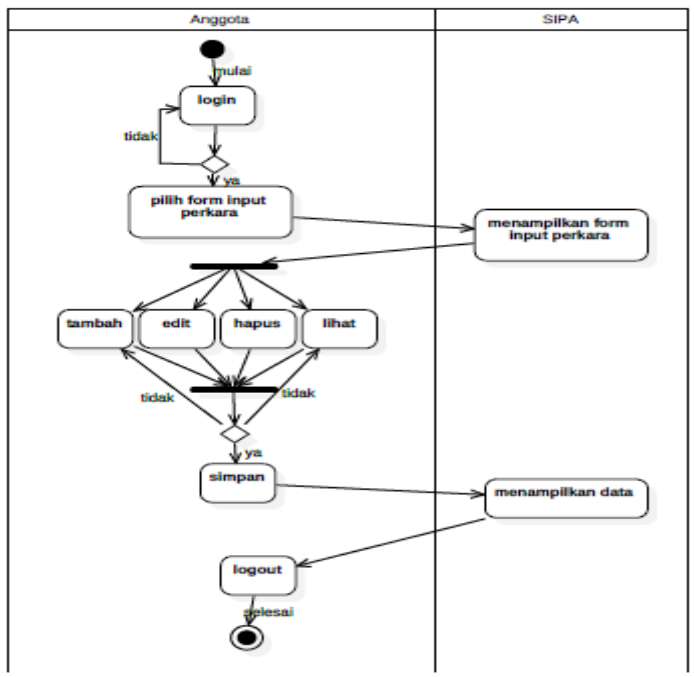

Gambar 3. Activity Diagram Anggota_Kelola Perkara

Sumber: Data Primer

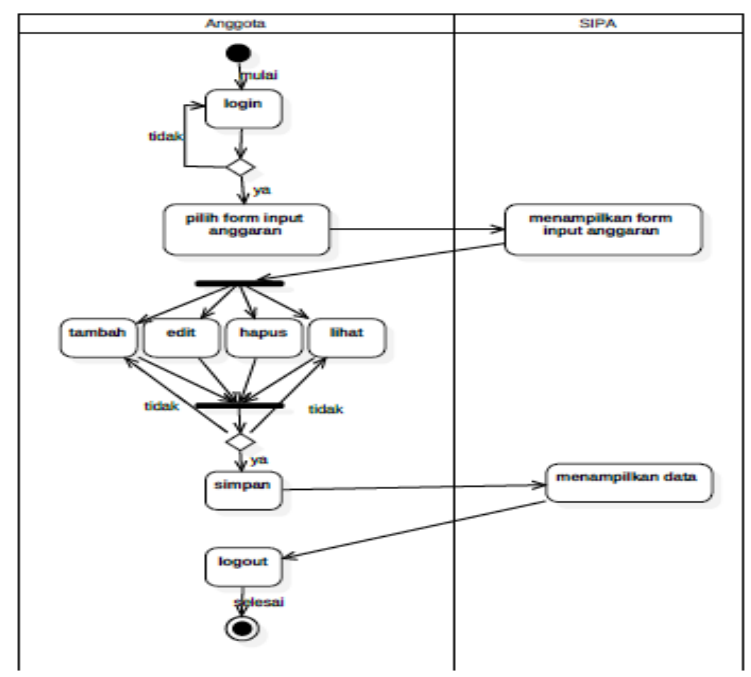

Gambar 4. Activity Diagram Anggota_Kelola Anggaran

Sumber: Data Primer

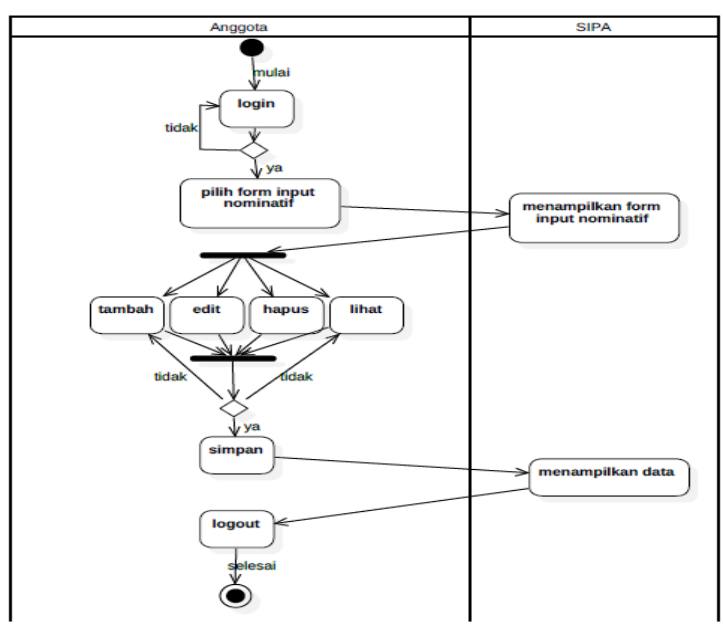

Gambar 5 Activity Diagram Anggota_KelolaNominatif Sumber: Data Primer

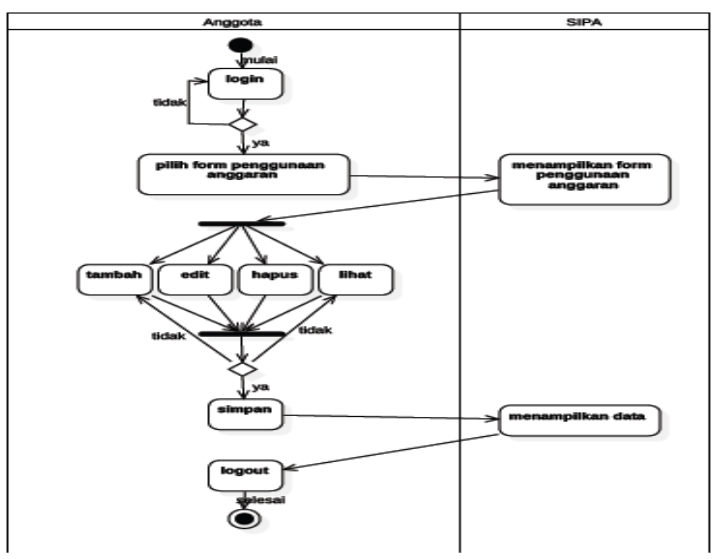


Gambar 6. Activity Diagram Anggota_Kelola Penggunaan Anggaran

Sumber: Data Primer

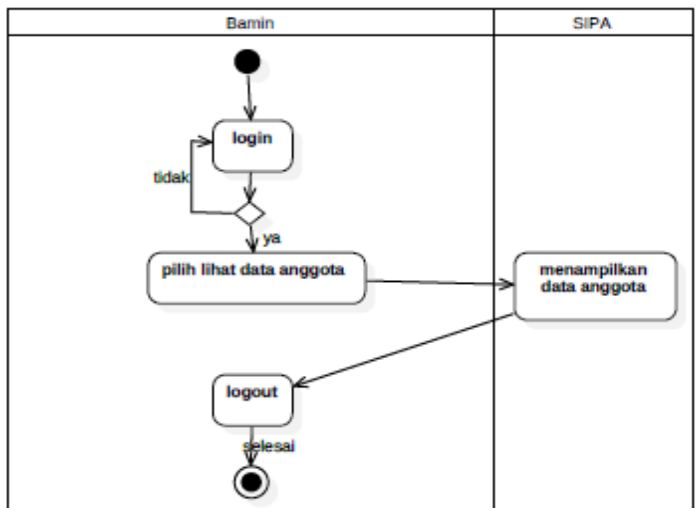

Gambar 7 Activity Diagram Bamin_KelolaAnggota Sumber: Data Primer

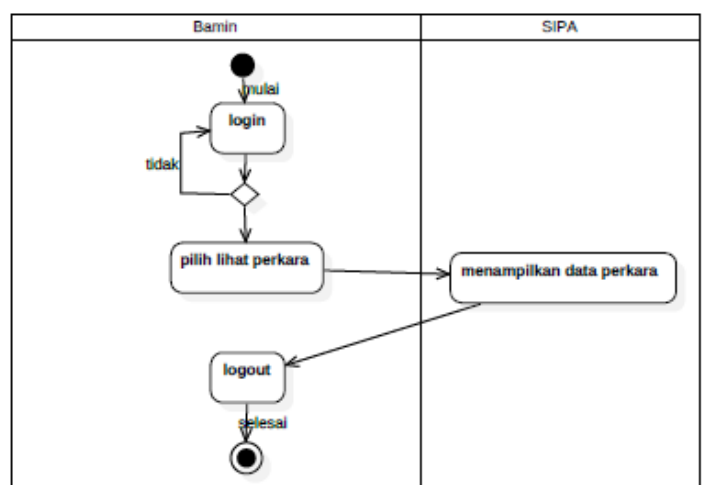

Gambar 8. Activity Diagram Bamin_KelolaPerkara Sumber: Data Primer

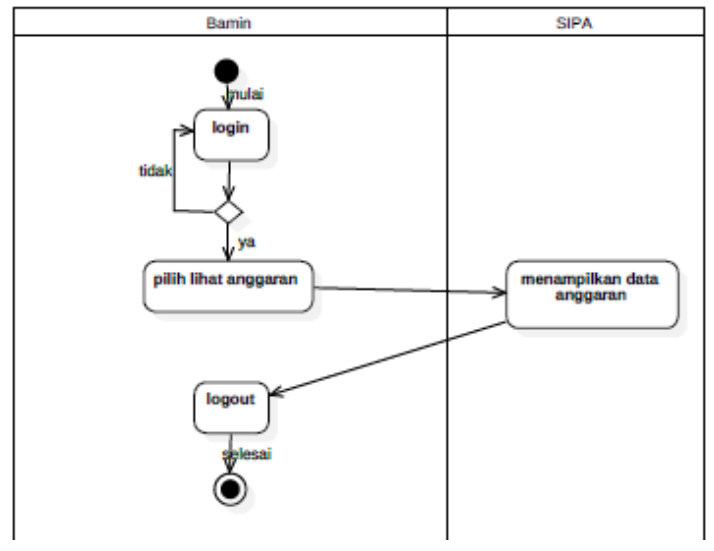

Gambar 9. Activity Diagram

Bamin_KelolaAnggaran

Sumber: Data Primer

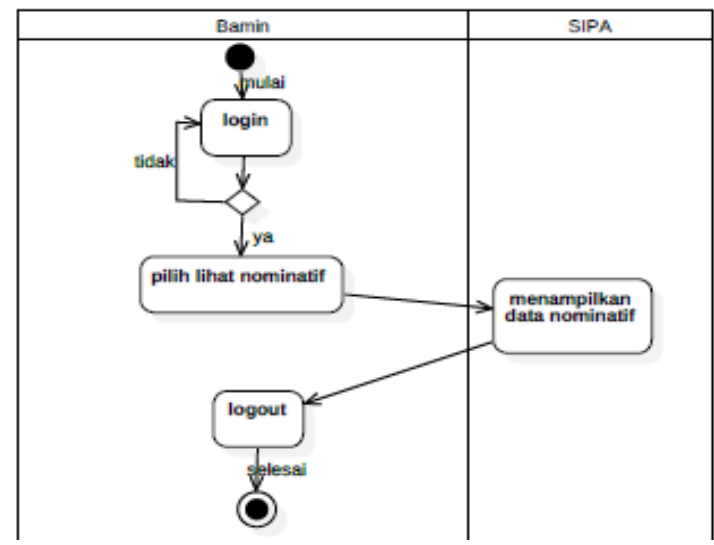

Gambar 10. Activity Diagaram

Bamin_KelolaNominatif

Sumber: Data Primer

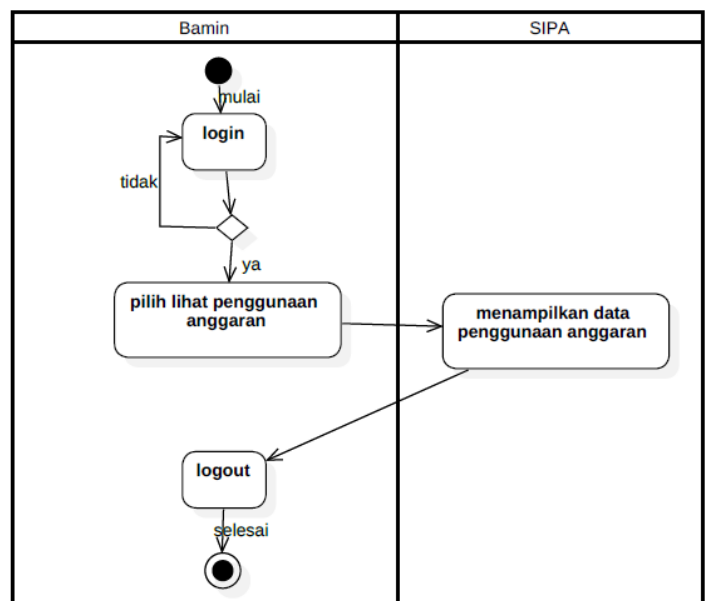

Gambar 11. Activity Diagram Bamin_Kelola Penggunaan Anggaran

Sumber: Data Primer

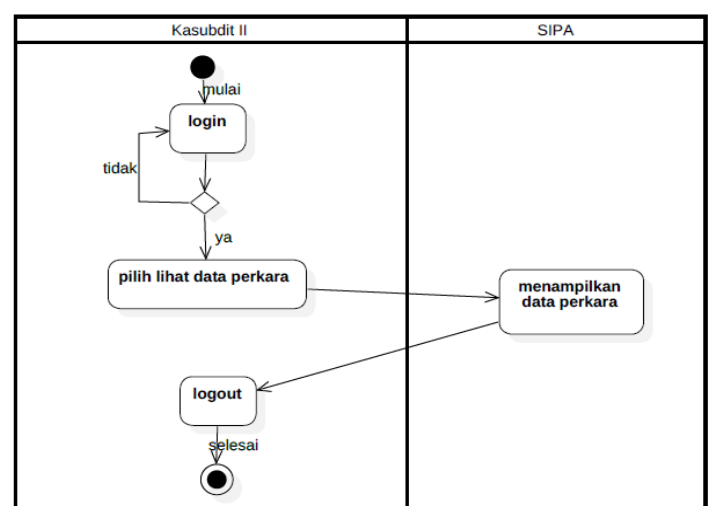

Gambar 12. Activity Diagram Kasubdit_KelolaPerkara

Sumber: Data Primer 


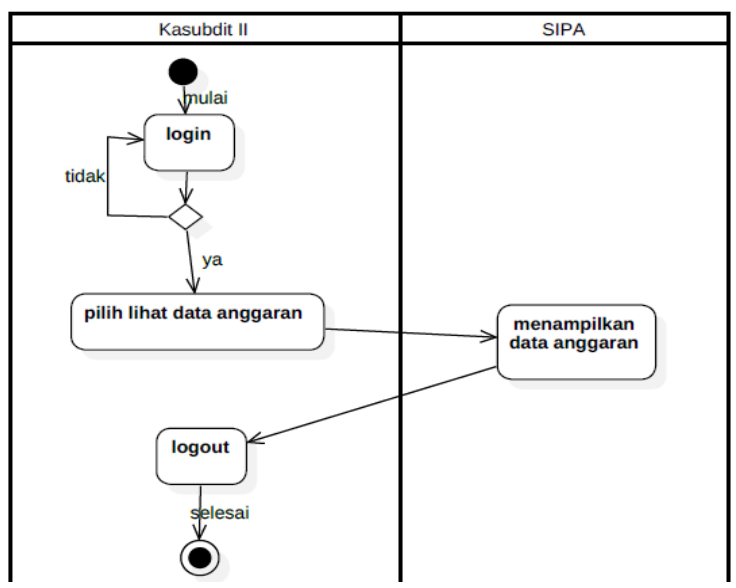

Gambar 13. Activity Diagram Kasubdit_Kelola

\section{Anggaran}

Sumber: Data Primer

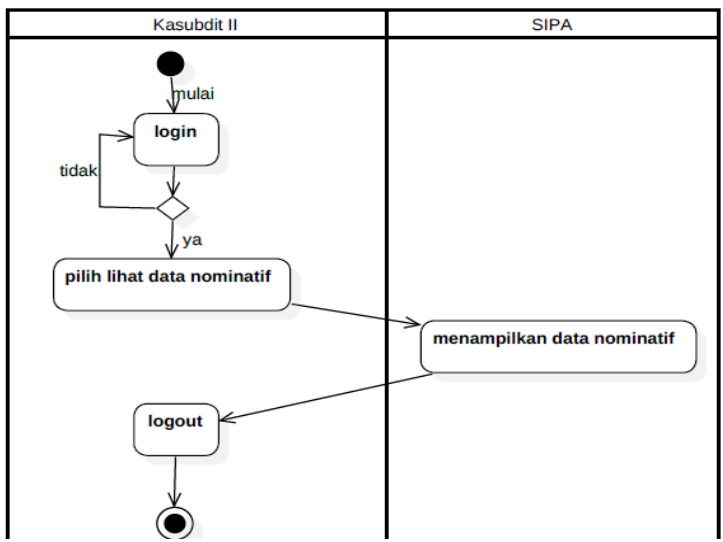

Gambar 14. Activity Diagram Kasubdit_Kelola Nominatif

Sumber: Data Primer

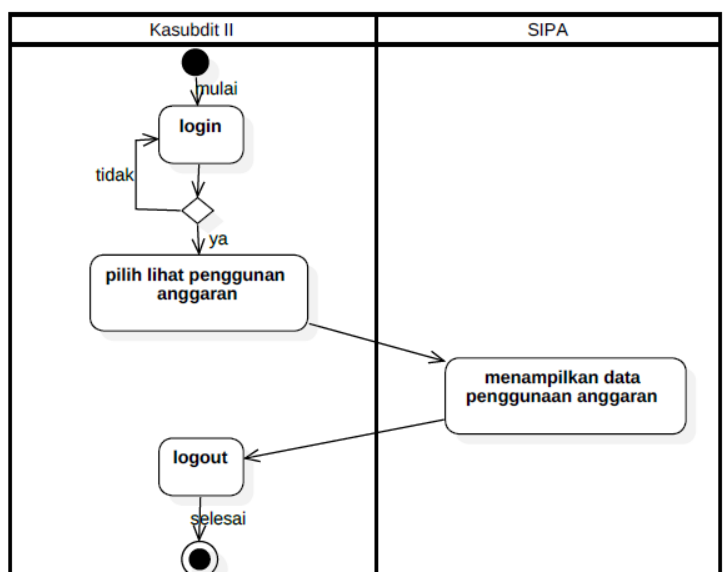

Gambar 15. Activity Diagram Kasubdit_Kelola Penggunaan Anggaran

Sumber: Data Primer

\subsection{Usecase Diagram}

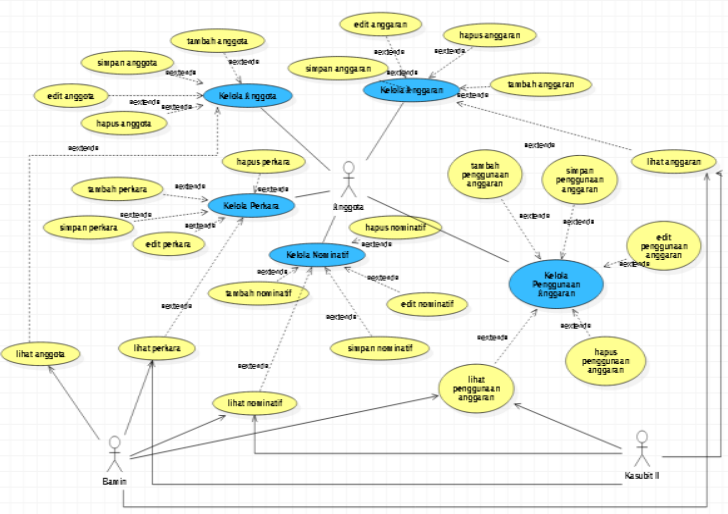

Gambar 16. Desain Diagram Usecase Sumber : Data Primer

\subsection{Sequence Diagram}

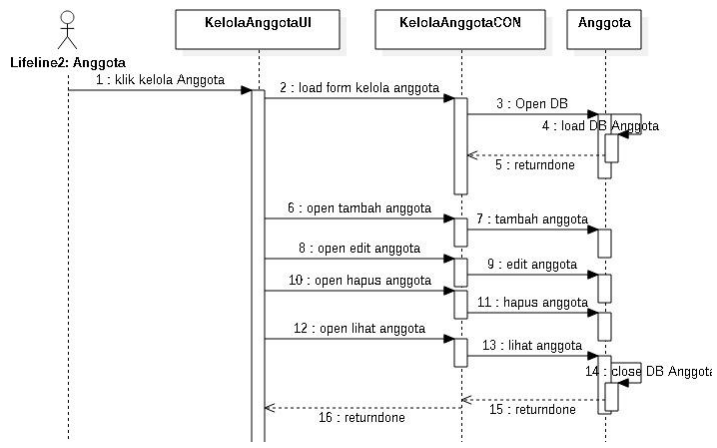

Gambar 17. Sequence Anggota_Kelola Anggota Sumber: Data Primer

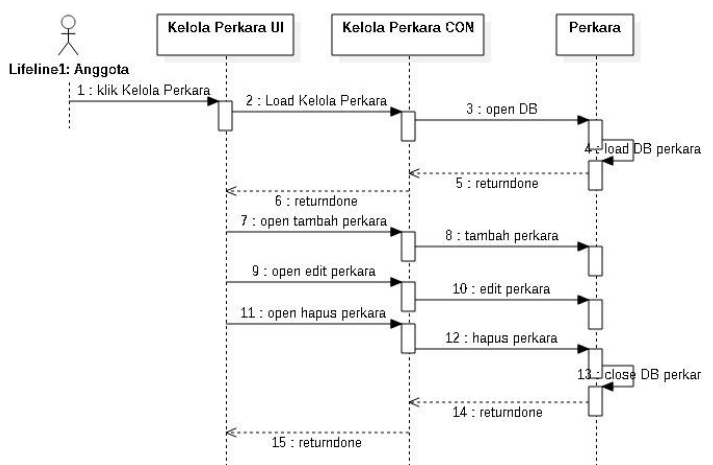

Gambar 18. Sequence Anggota_KelolaPerkara Sumber: Data Primer 


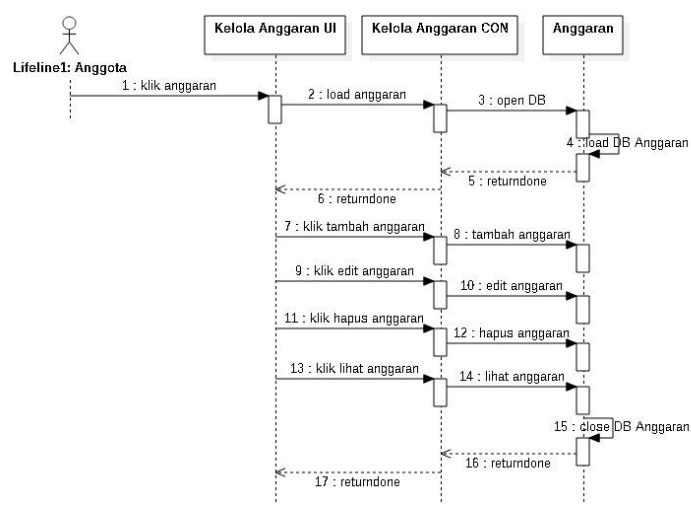

Gambar 19. Sequence Anggota_KelolaAnggaran Sumber: Data Primer

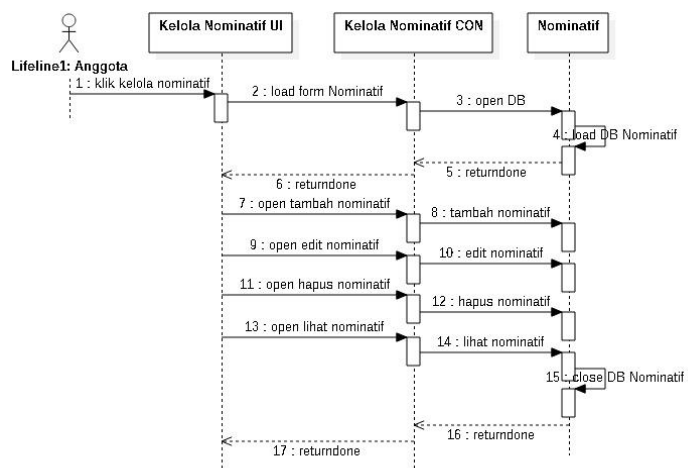

Gambar 20 Sequence Anggota_KelolaNominatif Sumber: Data Primer

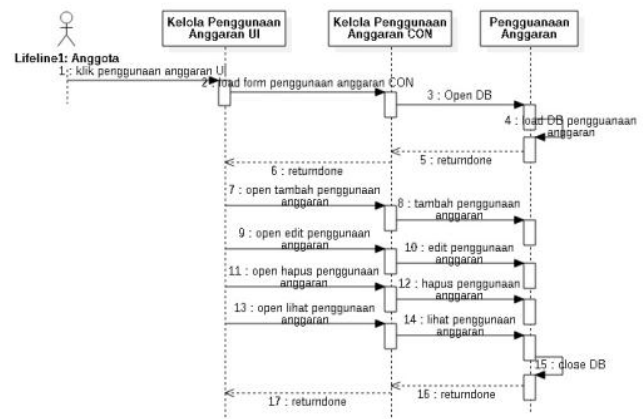

Gambar 21. Sequence Anggota_Kelola Penggunaan Anggaran

Sumber: Data Primer

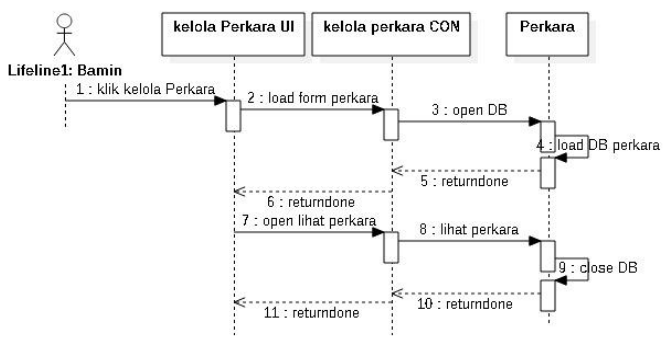

Gambar 22. Sequence Bamin_KelolaPerkara Sumber: Data Primer

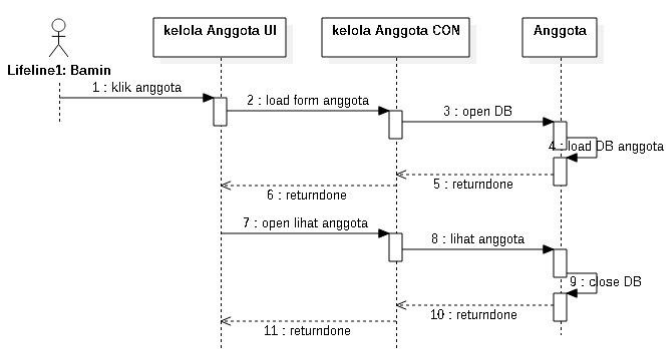

Gambar 23. Sequence Bamin_KelolaAnggota Sumber: Data Primer

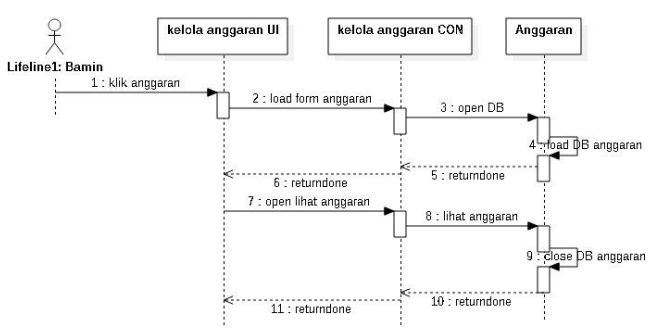

Gambar 24. Sequence Bamin_KelolaAnggaran Sumber: Data Primer

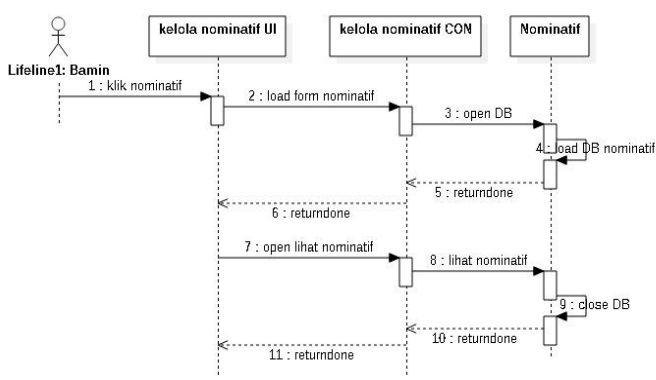

Gambar 25. Sequence Bamin_KelolaNominatif Sumber: Data Primer 


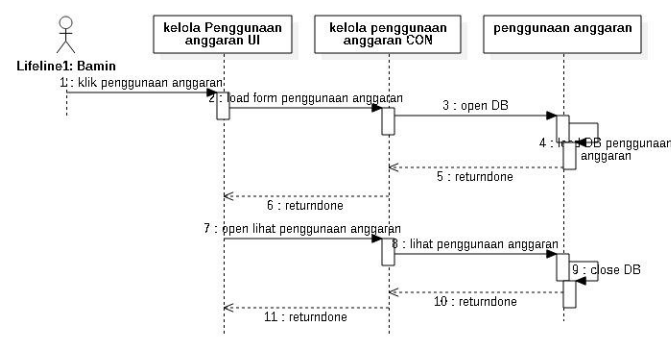

Gambar 26. Sequence Bamin_Kelola Penggunaan Anggaran

Sumber: Data Primer

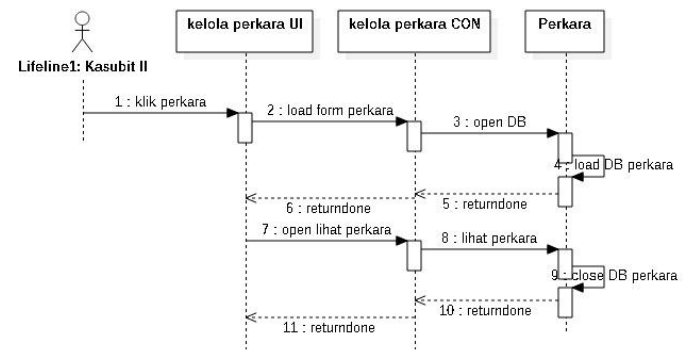

Gambar 27. Sequence KasubditII_KelolaPerkara Sumber: Data Primer

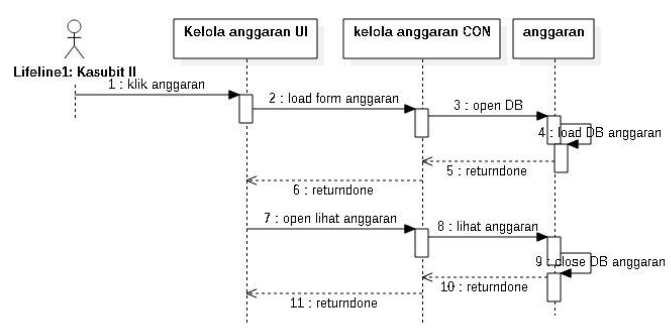

Gambar 28. Sequence KasubditII_KelolaAnggaran Sumber: Data Primer

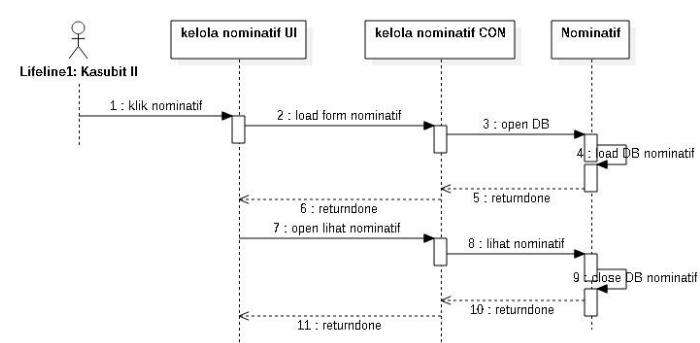

Gambar 29. Sequence KasubditII_KelolaNominatif Sumber: Data Primer

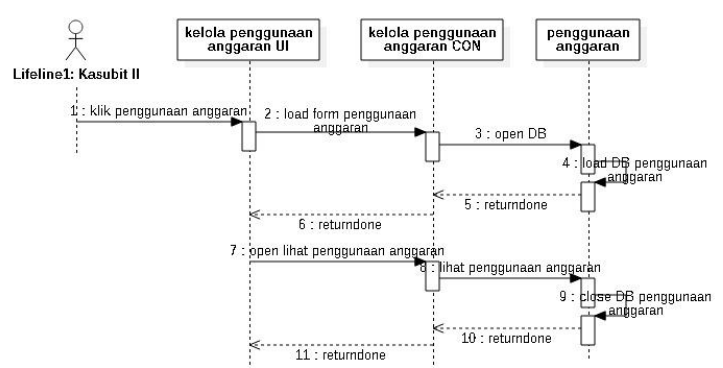

Gambar 30. Sequence KasubditII_Kelola Penggunaan Anggaran

Sumber: Data Primer

\subsection{Desain Interface}

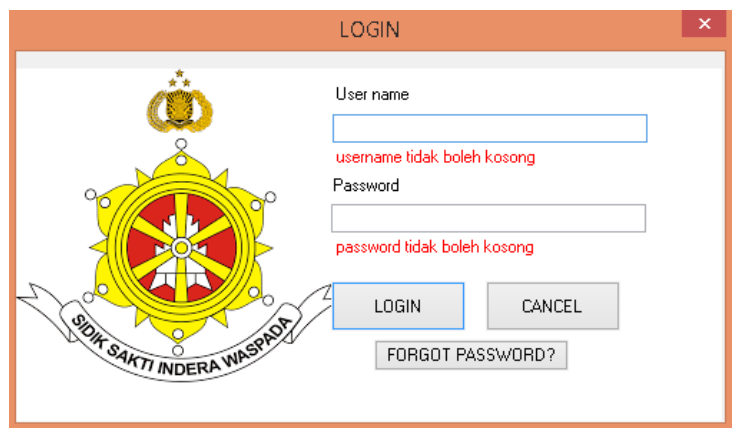

Gambar 31. Form Log in

Sumber: Data Primer

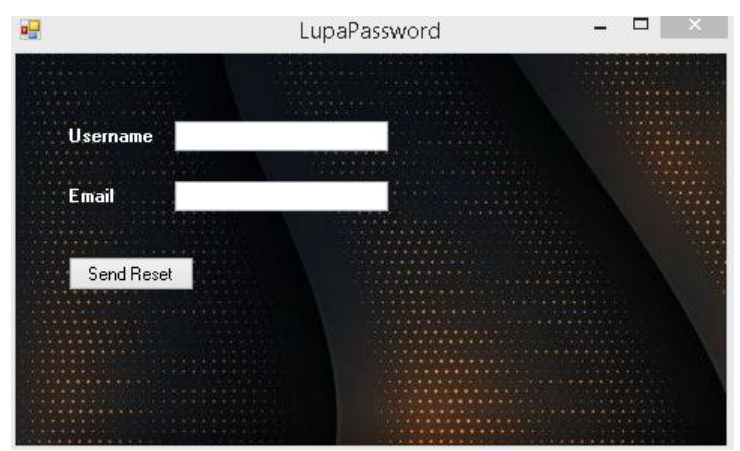

Gambar 32. Form Forgot Password Sumber: Data Primer

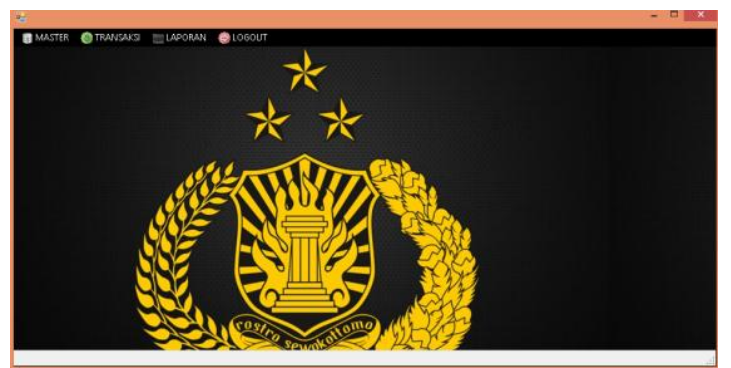

Gambar 33. Halaman Menu Utama Sumber: Data Primer 


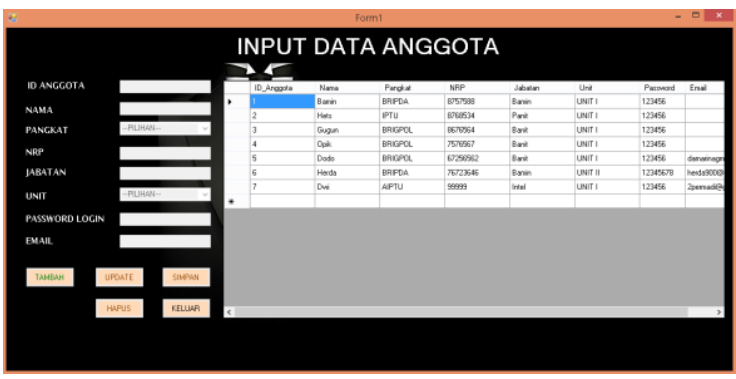

Gambar 34. Form Input Data Anggota Sumber: Data Primer

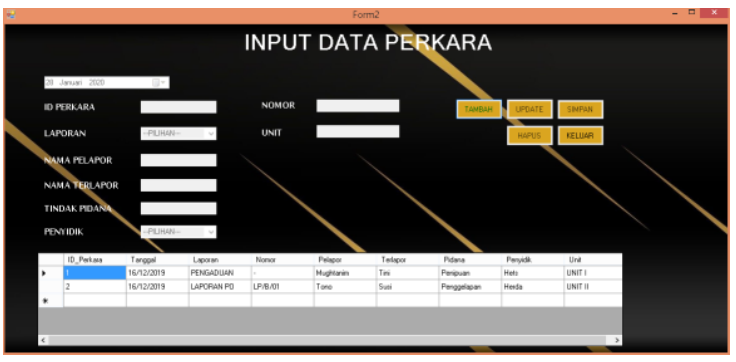

Gambar 35. Form Input Data Perkara Sumber: Data Primer

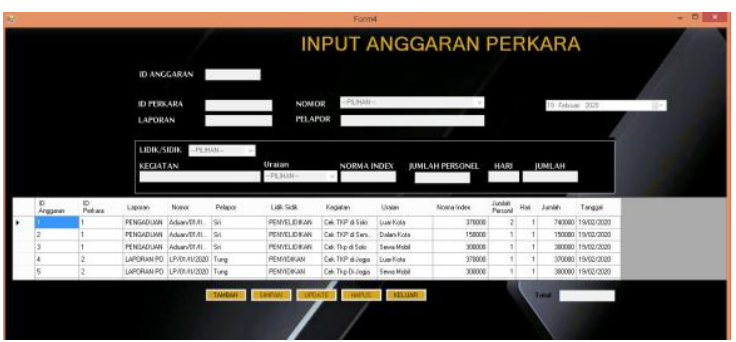

Gambar 36. Form Input Anggaran Perkara Sumber: Data Primer

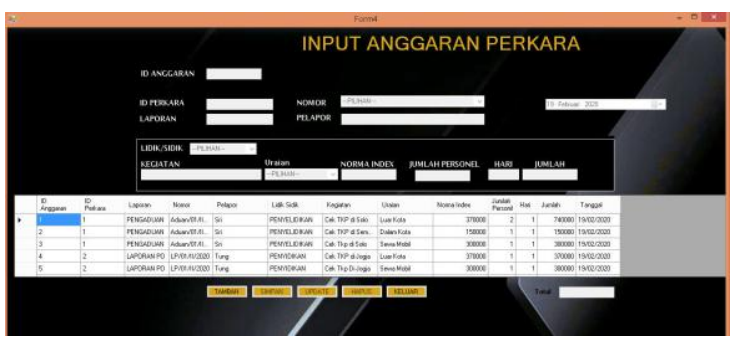

Gambar 37. Form Input Nominatif Sumber: Data Primer

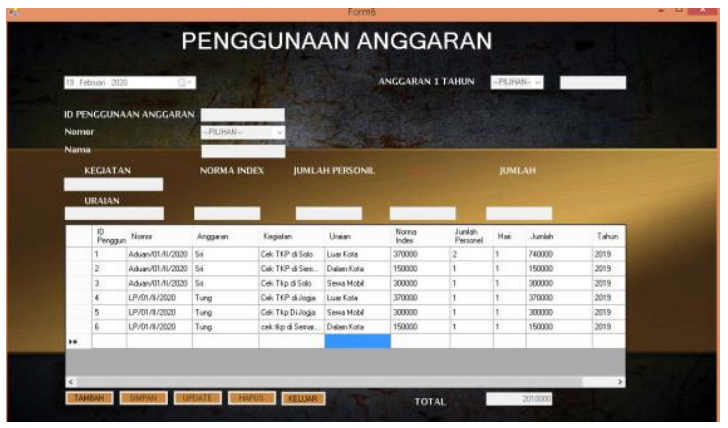

Gambar 38. Form Penggunaan Anggaran Sumber: Data Primer

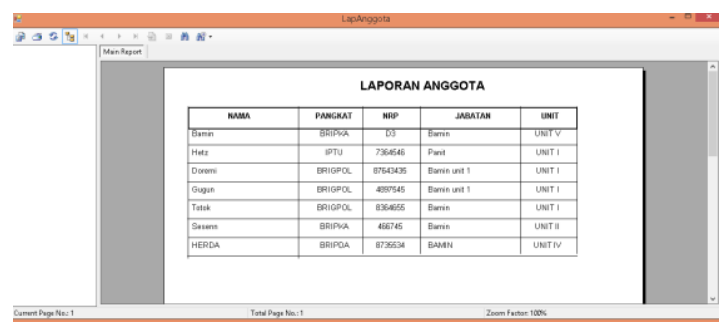

Gambar 39. Laporan Data Anggota Sumber: Data Primer

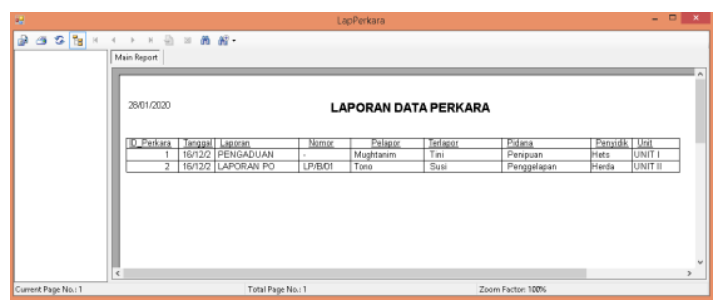

Gambar 40. Laporan Data Perkara Sumber: Data Primer

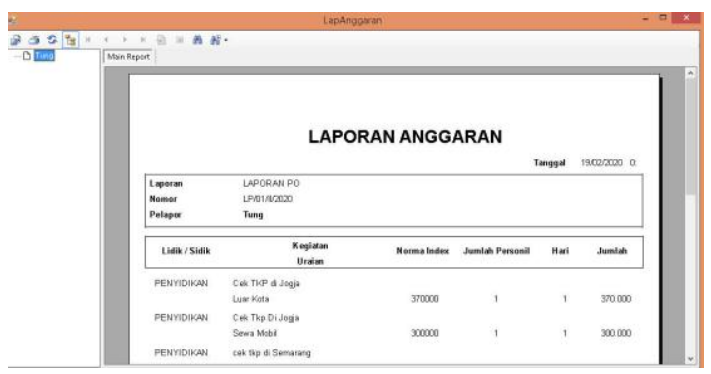

Gambar 41. Laporan Anggaran

Sumber: Data Primer 


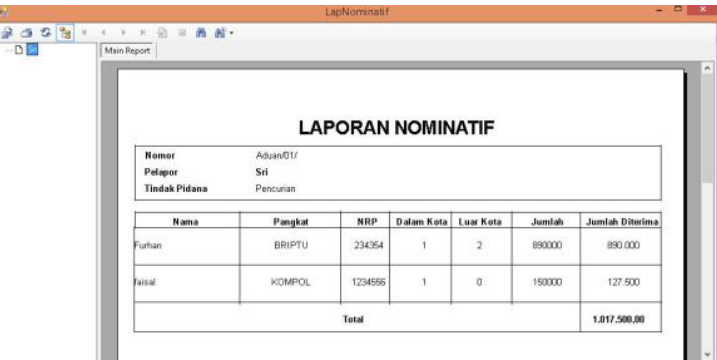

Gambar 42. Laporan Nominatif Sumber: Data Primer

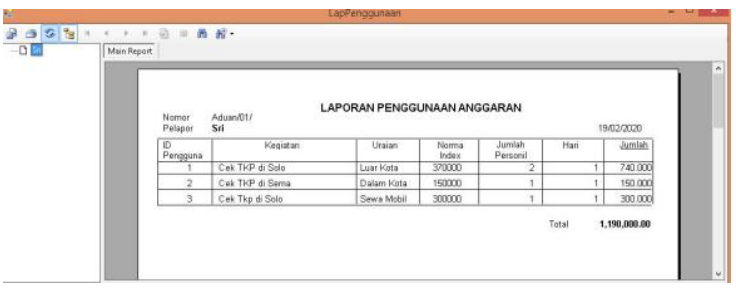

Gambar 43. Laporan Penggunaan Anggaran Sumber: Data Primer

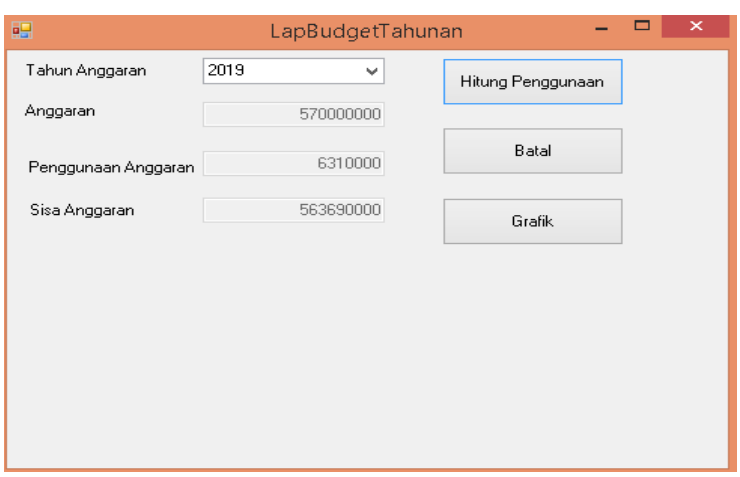

Gambar 44. Laporan Budget Tahunan

Sumber: Data Primer

\subsection{Diskusi Pengujian}

Pengujian perangkat lunak berfokus pada pengujiian persyaratan fungsional perangkat lunak, untuk mendapatkan serangkaian kondisi input yang sesuai dengan persyaratan fungsional program. Uji kelayakan rancangan dilakukan dengan menyerahkan produk pengembangan beserta jumlah angket kepada validator.
Penilaian didasarkan pada table skor berikut:

Tabel 1. Tabel Penilaian Kelayakan

\begin{tabular}{|c|l|}
\hline Skor & \multicolumn{1}{c|}{ Predikat } \\
\hline $0 \%-19,99 \%$ & Tidak Layak \\
\hline $20 \%-39,99 \%$ & Kurang Layak \\
\hline $40 \%-59,99 \%$ & Cukup Layak \\
\hline $60 \%-79,99 \%$ & Layak \\
\hline $80 \%-100 \%$ & Sangat Layak \\
\hline
\end{tabular}

Dengan menggunakan rumus $\mu=\Sigma x / \mathrm{n}$, diperoleh hasil perhitungan prosentase kelayakan sebesar $84 \%$. Nilai yang diperoleh menunjukan bahwa sistem yang dikembangkan sangat layak untuk digunakan. Diskusi dari pengujian pengguna (user) maka sistem sudah berjalan baik tetapi tidak menutup kemungkinan suatu saat terjadi kesalahan saat aplikasi digunakan, sehingga perlu maintenance untuk mengetahui kesalahan sistem agar dapat digunakan secara maksimal. Dari hasil diskusi pengujian, bahwa pengujian perangkat lunak penting dilakukan sebelum aplikasi digunakan oleh pengguna user. Selain itu validasi saat user login diperlukan sehingga jika tidak ada hak akses, maka tidak dapat masuk ke sistem agar data lebih aman. 


\section{Kesimpulan, Keterbatasan dan Saran}

\subsection{Kesimpulan}

Dengan adanya Sistem Informasi Pengelolaan Anggaran Perkara ini dapat memudahkan penginputan data pengelolaan anggaran dan mengetahui anggaran dengan cepat. Sistem ini dapat mengurangi potensi kesalahan pada saat akan mengajukan anggaran. Selain itu penyajian laporanlaporan dapat dilakukan dengan cepat sehingga dapat lebih efisien. Hasil pengisian angket oleh pakar menunjukkan hasil presentase kelayakan $84 \%$, yang berarti sistem dapat bekerja dengan baik serta sangat layak untuk digunakan.

\subsection{Keterbatasan}

Dalam penelitian ini memiliki keterbatasan yaitu sistem informasi ini hanya dapat digunakan secara offline. Penggunaan sistem hanya dapat dilakukan oleh anggota Subdit 2 Ditreskrimum Polda Jateng. Selain itu, halaman forgot password (lupa kata sandi) hanya bisa konfirmasi ke e-mail untuk mengetahui password lama.

\subsection{Saran}

Saran untuk pengguna sistem adalah perlu dilakukan pengawasan terhadap sistem dan dilakukan pengembangan berkelanjutan agar dapat digunakan oleh bagian lain dalam pengelolaan anggaran secara efisien dan efektif. Bagi peneiti selanjutnya dapat mengembangkan tampilan website lebih menarik dan lebih memudahkan pengguna. Perlu adanya tambahan pada sistem keamanan forgot password agar dapat mengubah kata sandi yang lama dengan yang baru, serta menambahkan enkripsi password. Peneliti selanjutnya dapat terus mengembangkan metode sistem yamg baru yang berhubungan dengan anggaran dan dikembangkan menjadi online hingga akses lebih mudah digunakan oleh internal.

\section{Refrensi}

Ai Rosita. (2018). Perancangan Sistem Informasi Perencanaan dan Kontrol Anggaran di Perguruan Tinggi (Studi Kasus Pada Universitas Widyatama Bandung). Konfrensi Nasional Sistem Informasi STIMIK Atmaluhur Pangkal Pinang, 8-9 Maret 2018.

Anita, K., Irwinsyah. (2019). Aplikasi Akuntansi Anggaran Belanja Dan Realisasi Pada Madrasah Aliyah AlHikmah Bandar Lampung. Jurnal Sistem Informasi Akuntansi, vol. 2, no. 1, pp. 9-14.

Arta, M., Herlin, T. Irene, P. (2011). Sistem Informasi Budgeting untuk Perguruan Tinggi. Seminar Nasional Informatika (SEMNASIF) UPN Veteran Yogyakarta, 2 Juli 2011.

Astarina,Y.(2019). Perancangan Sistem Informasi Anggaran Pada STIE Lembah Dempo Pagar Alam. Jurnal Sistem Informasi Komputer dan Teknologi Informasi (SISKOMTI), vol. 1 , no. 1 , pp. $40-54$.

Kusnendi, M. S. (2014). Konsep Dasar Sistem Informasi. Konsep Dasar Sistem Informasi.

Eka, M. S. R., Aeri, R. (2016). "Sistem 
Informasi Anggaran Belanja". Jurnal Ilmiah NERO, Vol. 2, No. 2, pp. 8389.

Fitri, A., Tholib, H., Chairul, A. (2019). Perancangan Sistem Informasi Akuntansi Berbasis VB.Net di PT Indoland Development. Exact Papers In Compilation (EPIC), vol. 1, no. 1 pp. 27-34.

Husen, Alam, R., \& Heni, S. (2017). Sistem Informasi Manajemen Anggaran ( Simangga ) Perguruan Tinggi Berbasis Web ( Studi Kasus : Universitas Siliwangi ), Jurnal Edukasi dan Penelitian Informatika (JEPIN), vol. 3, no. 2, pp. 89-95.

Kusrini, Koniyo Andri. (2007). Membangun Sistem Informasi Akuntansi dengan Visual Basic dan Microsoft SQL. Andi Offset: Yogyakarta.

Mulyanto, A. (2015). Pengertian Informasi menurut Agus Mulyanto. Pengertian Sistem Informasi dan sistem informasi akutansi Akuntansi.

Nining, R., dan Kaslani. (2018). Sistem Informasi Anggaran Menggunakan Metode Sistem Development Live Cycle untuk Menghasilkan Data yang Akurat. Jurnal Komputer Akuntansi, Vol. 5, No. 1.

Sukarta, I. W., Badera, I. D. N., \& Ratnadi, N. M. D. (2017). Pengaruh Kompetensi, Pemanfaatan Teknologi Informasi, Komitmen Dan Revisi Anggaran Pada Efektivitas Pengelolaan Anggaran Universitas Udayana. E-Jurnal Ekonomi dan Bisnis Universitas Udayana, vol. 11, pp. 3917-3950.

Sugiyono. (2016). Metode Penelitian dan Pengembangan (Research and Development/R\&D). Bandung: Alfabeta.

Sutabri, T., \& Napitupulu, D. (2019). Sistem Informasi Bisnis. Sistem Informasi Bisnis.

Wang, Y., \& Kogan, A. (2018). Designing confidentiality-preserving Blockchainbased transaction processing systems.
International Journal of Accounting Information Systems.

Windi, I., Eka, S. (2018). Sistem Informasi Anggaran Pendapatan dan Belanja Desa Berorientasi Objek. Jurnal Khatulistiwa Informatika, Vol. 5, No. 1 Zarnelly. (2017). Sistem Informasi EBudgeting Menggunakan Pendekatan Berorientasi Objek (Studi Kasus: UIN Suska Riau). Jurnal Ilmiah Rekayasa dan Manajemen Sistem Informasi, Vol. 3, No. 1, Hal 70-77. 